\title{
Patofisiologi Penurunan Kognitif pada Penyakit Parkinson
}

\section{Suharti ${ }^{*}$}

${ }^{1}$ Program Magister Ilmu Biomedik, Departemen Fisiologi kedokteran, Fakultas Kedokteran Universitas Indonesia

*Email Korespondensi: suhartibintisidik@gmail.com, Telp: 085743464731

\begin{abstract}
ABSTRAK
Penyakit Parkinson (PD) merupakan penyakit yang mengganggu pergerakan dan merupakan penyakit degeneratif sistem saraf pusat yang paling umum setelah Alzheimer. Parkinson biasanya terjadi pada usia 65 hingga 70 tahun. Kasus sebelum usia 40 tahun terjadi kurang dari 5\%. Patologi pada PD ditandai oleh hilangnya intervasi neuron dopaminergik di subsantia nigra. Neurodegerasi PD tidak terbatas hanya pada neuron dopaminergik di substantia nigra, namun juga melibatkan sel-sel yang berlokasi di area otak lain yang saling terkoneksi. Gangguan motorik terjadi pada PD. Namun, seiring dengan perkembangan penyakit, dapat terjadi gangguan non-motorik seperti penurunan indra penciuman, disfungsi otonom, nyeri, kelelahan, gangguan tidur, gangguan kognitif dan psikiatrik. Penurunan kognitif, dalam bentuk penurunan fungsi eksekutif, visuospasial dan memori, serta demensia, merupakan aspek gangguan non-motorik dari penyakit parkinson. Hal tersebut berefek secara signifikan terhadap kualitas hidup penderita PD. Pemahaman terkait patologi yang mendasari penurunan kognitif pada PD memungkinkan dilakukannya intervensi dini dalam pencegahan perkembangan PD yang mengarah pada gangguan non-motorik. Neuropatologis utama PD adalah keberadaan Lewy bodies yang mengandung $\alpha$-synuclein dan hilangnya neuron dopaminergik di substantia nigra, yang bermanifestasi penurunan fasilitasi gerakan sadar. Sejalan dengan perkembangan PD, patologi Lewy bodies menyebar ke daerah neokortikal dan kortikal. Neurodegenerasi daerah kortikal dan limbik yang luas, deposisi Lewy bodies, neuroinflamasi, small vascular disease (SVD), dan faktor genetik terlibat dalam penurunan fungsi kognitif pada PD.
\end{abstract}

Kata kunci: Penyakit parkinson; penurunan kognitif; neuropatologis

Article history:

Received: 1 May 2020

Accepted: 23 June 2020

Publish Online: 30 June 2020

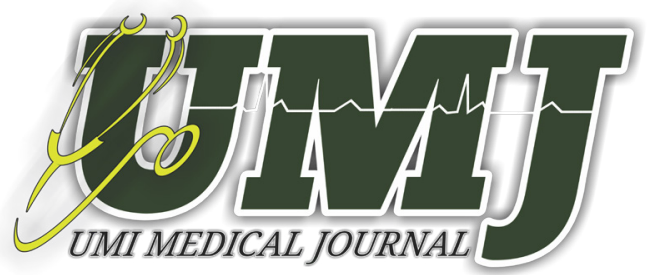

Published By :

Fakultas Kedokteran

Universitas Muslim Indonesia

Phone:

+6282293330302
Address:

Jl. Urip Sumoharjo Km. 5 (Kampus II UMI)

Makassar, Sulawesi Selatan.

Email:

medicaljournal@umi.ac.id 


\begin{abstract}
Parkinson's disease (PD) is a disease that interferes with movement and is the most common degenerative central nervous system disease after Alzheimer's. Parkinson's usually occurs at the age of 65 to 70 years. Cases before the age of 40 years occur less than 5\%. Pathology in PD is characterized by the loss of the interventions of dopaminergic neurons in subsantia nigra. Neurodegeration is not limited to dopaminergic neurons in the substantia nigra, but also involves cells located in other areas of the brain that are interconnected. Motor disturbances occur in PD, along with the development of the disease, non-motor disorders can occur such as decreased sense of smell, autonomic dysfunction, pain, fatigue, sleep disorders, cognitive and psychiatric disorders. Cognitive decline, in the form of decreased executive function, visuospatial and memory, and dementia, is a non-motoric aspect of Parkinson's disease. This has a significant effect on the quality of life of PD sufferers. Understanding the pathology associated with cognitive decline in PD allows early intervention in preventing the development of PD that leads to nonmotor disorders. The main neuropathological PD is the presence of Lewy bodies containing a-synuclein- and the loss of dopaminergic neurons in the substantia nigra, which manifests a decrease in facilitation of conscious movements. In line with the development of PD, Lewy bodies' pathology spread to neocortical and cortical regions. Neurodegeneration of broad cortical and limbic regions, Lewy body deposition, neuroinflammation, SVD, and genetic factors are involved in cognitive decline in PD.
\end{abstract}

Keywords: Parkinson's disease; cognitive decline; neuropathology

\title{
PENDAHULUAN
}

Penyakit Parkinson (PD) merupakan penyakit yang mengganggu pergerakan dan merupakan penyakit degeneratif sisem saraf pusat yang paling umum setelah Alzheimer. Parkinson pertama dijelaskan oleh James Parkinson pada 1817. Adapun tanda-tanda dari PD adalah bradikinesia (melambatnya gerak anggota tubuh), kekakuan dan tremor, dan gejala mental.(1)

Parkinson biasanya terjadi pada usia 65 hingga 70 tahun. Kasus sebelum usia 40 tahun terjadi kurang dari 5\%. Onset yang lebih awal bisa terjadi pada seseorang yang memiliki riwayat genetik. Monogenetik dari PD jarang ditemukan, tetapi dapat ditemukan pada etnis tertentu. Secara umum faktor genetik terlibat sekitar 5-10\% dari kasus parksinson. Parkinson terjadi lebih sering pada pria daripada wanita. Prevalensi penyakit ini berkisar 100-200 per 100.000 orang dan insiden tahunannya sekitar 15 per 100.000 orang.(1)

Patologi pada PD ditandai oleh hilangnya intervasi neuron dopaminergik di subsantia nigra. Kerusakan neuron dopaminergik ini secara seluler berkaitan dengan agregasi $\alpha$-synuclein, yang membentuk Lewy bodies dan Lewy neurites. Neurodegerasi PD tidak terbatas hanya pada neuron dopaminergik di substantia nigra, namun juga melibatkan sel-sel yang berlokasi di area otak lain yang saling terkoneksi. Fase pre-motor atau prodromal dimulai sekitar 12-14 tahun sebelum PD terdiagnosis. Kerusakan awalnya terjadi pada sistem saraf otonom perifer dan atau olfactory bulb, dengan patologi yang kemudian menyebar ke sistem saraf pusat, lalu ke struktur bawah batang otak hingga akhirnya memengaruhi substantia nigra.(2) 
Gejala awal PD umumnya muncul secara asimetris tanpa adanya gejala atipikal (disfungsi otonom, hilangnya kemampuan sensorik kortikal, dan kelumpuhan supranuklear vertikal). Seiring dengan perkembangan penyakit, gejala motorik akan semakin memburuk dan dapat terjadi gejala non-motorik seperti penurunan indra penciuman, disfungsi otonom, nyeri, kelelahan, gangguan tidur, gangguan kognitif dan psikiatrik. Hal tersebut berefek secara signifikan terhadap kualitas hidup penderita PD.(2)

Penurunan kognitif, dalam bentuk penurunan fungsi eksekutif, visuospasial dan memori, serta demensia, merupakan aspek non-motorik dari penyakit parkinson. Gangguan kognitif ringan (Mild cognitive impairment/ MCI) adalah ciri umum dari penyakit Parkinson, bahkan pada tahap paling awal penyakit. Namun, terdapat variasi MCI terkait sifat dan tingkat keparahan keterlibatan kognitif dan risiko perubahan menjadi demensia penyakit Parkinson.(3) MCI memengaruhi sekitar 20-50\% orang dengan PD, dan studi longitudinal menunjukkan pengaruh hingga $80 \%$ pada demensia PD.(4)

Demensia penyakit Parkinson adalah penentu penting dari penurunan harapan hidup pada pasien parkinson. Demensia terjadi pada $50 \%$ pasien pasca 10 tahun diagnosis Parkinson. Pemahaman yang baik mengenai patologi dan progresi dari perubahan kognitif pada pasien Parkinson memungkinkan dilakukannya intervensi dini.(3)

Artikel ini akan membahas patofisiologi penurunan fungsi kognitif terutama penurunan fungsi memori pada penyakit Parkinson. Informasi yang diperlukan dalam penyusunan artikel ini diperoleh dari jurnal maupun buku terkait PD. Jurnal terkait PD diperoleh dari berbagai sumber seperti PubMed, NCBI, Elsevier, dan Hindawi dengan beberapa kata kunci seperti Parkinson's disease, Epidemiology, Cognitive impairment in Parkinson's disease, Lewy body, LRRK2, dan patofisiologi.

\section{A. Penyakit Parkinson}

Penyakit Parkinson merupakan penyakit neurodegeratif terkait pergerakan yang paling umum terjadi. Di Eropa, prevalensi dan insiden terjadinya PD sekitar 108-257/100,000 orang dan 11-19/100,000 orang per tahun.(5) Prevalensi PD di Asia berkisar 51- 176/100,000 orang pertahun.(6) Sebuah survei yang dilakukan di Asia Tengah dan negara Transkauasia menunjukkan prevalensi PD berkisar 62/100,000 orang per tahun, dengan rata-rata onset usia terjadinya PD pada perempuan adalah $56.4 \pm 2.8$ tahun dan pada laki-laki 63.3 \pm 3.5 tahun.(7) Secara global prevalensi PD meningkat dengan usia dan PD memengaruhi 1\% dari populasi di atas 60 tahun.(1)

PD merupakan penyakit neurodegeneratif progresif yang dicirikan dengan gangguan motorik (seperti bradikinesia, tremor istirahat, kekakuan, dan instabilitas postural), onset gejala asimetris, dan respon yang baik untuk levodopa.(8,9). Gangguan motorik disebabkan karena hilangnya neuron dopaminergik substantia nigra pars compacta, dengan patologi intraseluler berhubungan dengan agregasi $\alpha$-synuclein, yang membentuk Lewy bodies dan Lewy neurites. Beberapa mekanisme lain yang terlibat dalam PD, diantaranya meliputi disfungsi mitokondria, penurunan mekanisme pembersihan protein non fungsional, dan neuroinflamasi. Namun, interaksi antara berbagai faktor tersebut belum sepenuhnya diketahui.(2) 
Faktor resiko untuk PD meliputi usia, jenis kelamin, dan faktor lingkungan (6). Penyebab monogenetik PD telah diidentifikasi, tetapi dianggap sangat langka hingga mutasi leusin-rich repeat kinase 2 (LRRK2) teridentifikasi pada suatu populasi yang menyebabkan hingga 40\% kasus. Faktor risiko lingkungan dari PD dapat mendukung faktor risiko genetik dalam menimbulkan penyakit. Merokok, konsumsi alkohol, paparan

vitamin $\mathrm{D}$, dan tingkat asam urat adalah contoh faktor lingkungan yang mungkin memengaruhi timbulnya penyakit.(1)

Terjadi peningkatan kejadian penyakit neurodegeneratif seperti Amyotrophic lateral sclerosis (ALS) dan PD di Norwegia. Sebagian besar peningkatan dikaitkan dengan peningkatan harapan hidup dalam populasi. Namun, data yang baru-baru ini diterbitkan menunjukkan peningkatan risiko PD, terutama pada pria. Dihipotesiskan bahwa peningkatan risiko PD bisa terkait dengan perubahan perilaku merokok setelah abad kedua puluh. Peningkatan kejadian PD juga terkait dengan peningkatan polusi udara.(1)

Sebuah penelitian di Denmark menunjukkan peningkatan risiko PD yang jelas pada pasien dengan diagnosis konstipasi sebelumnya. Selain itu, hal tersebut juga dilaporkan dalam penelitian lain. Hiposmia dan gangguan tidur REM dikaitkan pula dengan risiko PD. REM sleep behaviour disorder (RBD) pada lebih dari 50\% kasus berakhir sebagai penyakit terkait sinukleinopati terutama PD, setelah 10 hingga 20 tahun pengamatan.(1)

RBD ditandai dengan hilangnya atonia otot normal selama tidur REM menyebabkan pasien bertindak dalam mimpi mereka. Data menunjukkan bahwa RBD dapat mendahului gejala motorik pada hampir 50\% pasien dan terjadi pada sekitar setengah dari pasien dengan penyakit Parkinson. Gejala-gejala gangguan tidur yang umum pada PD diantaranya melamun, somnolen dan kemungkinan terjadi bersamaan dengan gejala gerakan PD seperti kaki gelisah dan gerakan tungkai periodik selama tidur.(9)

Anosmia, atau kehilangan indera penciuman, ditemukan pada $70 \%-100 \%$ pasien dengan penyakit Parkinson. $(9,10)$ Anosmia mungkin mencerminkan degenerasi dan disfungsi yang terjadi lebih awal dan lebih parah pada sirkuit saraf yang bertanggung jawab untuk penciuman daripada di daerah otak yang terlibat dalam kontrol motorik. Gangguan penciuman sangat umum sehingga menjadi fokus dari untuk mengembangkan diagnosis premotor pada penyakit Parkinson.(9)

\section{B. Neuropatologis Parkinson}

Neuropatologis utama PD adalah keberadaan Lewy bodies yang mengandung $\alpha$-synuclein dan hilangnya neuron dopaminergik di substantia nigra, yang bermanifestasi penurunan fasilitasi gerakan sadar. Dengan perkembangan PD, patologi Lewy bodies menyebar ke daerah neokortikal dan kortikal.(1)

\section{B.1. Lewy bodies}

Lewy bodies sebagian besar terdiri dari protein $\alpha$-synuclein, protein 140 -asam amino yang fungsinya belum diketahui. Peran Lewy bodies dalam menyebabkan PD (serta demensia dengan Lewy bodies dan penyakit Alzheimer) tidak jelas. Mutasi pada gen yang mengkode $\alpha$-synuclein, yaitu SNCA menyebabkan peningkatan agregasi protein dan degenerasi saraf. Hal ini menunjukkan hubungan agregasi protein dengan timbulnya penyakit. Namun, hubungan sebab akibat antara Lewy bodies dan kematian sel saraf masih belum jelas.(8) 
Penelitian terhadap gangguan terkait (terutama, penyakit Huntington) menunjukkan struktur agregat protein terorganisir yang terlihat seperti Lewy bodies bisa bersifat protektif. Penelitian ini menunjukkan bahwa jika sel memiliki agregat protein yang mengganggu di sitoplasma neuron, sel akan merespons dengan menarik semua agregat ini ke dalam satu bagian sel untuk membentuk struktur khusus. Dalam kasus PD akan terbentuk Lewy bodies. Dengan demikian, kerusakan yang disebabkan oleh agregat protein pada organel dan proses seluler dapat ditekan. Karena mayoritas analisis Lewy bodies berasal dari sampel postmortem, yang menurut definisi memberikan ukuran patologi yang statis. Selain itu, tidak ada model hewan yang relevan secara fisiologis yang menggambarkan patologi Lewy bodies, sehingga agak sulit untuk menguji hipotesis ini secara langsung.(8)

Sebuah informasi menarik mengenai biologi Lewy bodies ditunjukkan oleh penggunaan implan sel janin sebagai pengobatan eksperimental untuk PD selama 1980-an dan 1990-an. Meski secara klinis hasil terapi penggantian sel ini beragam, sejumlah pasien yang diobati dengan sel-sel ini menjalani pemeriksaan neuropatologis postmortem. Ketika daerah yang menjadi sasaran terapi penggantian sel diperiksa, dua pengamatan penting dilakukan. Pertama, sebagian sel janin bertahan dan berhasil diintegrasikan ke dalam ganglia basal. Kedua, tampaknya ada patologi Lewy bodies dalam sel-sel baru. Hal ini menunjukkan bahwa agregasi $\alpha$-synuclein ke dalam Lewy bodies dapat menyebar dari sel-sel tua sakit yang mengelilingi implan ke dalam sel-sel yang baru terintegrasi. Ini mendukung model untuk patologi $\alpha$-synuclein di otak di mana proses transmisi agregat protein terjadi, yang mungkin analog dengan yang terlihat pada gangguan prion.(8)

\section{B.2. Hilangnya neuron dopaminergik}

Neuropatologis PD selain keberadaan Lewy bodies yang mengandung a-synuclein juga meliputi hilangnya neuron dopaminergik di substantia nigra. Aspek neurodegenerasi pada PD berpusat pada hilangnya neuron yang terjadi akibat respons reaktif dari sel glial dan sistem imun di otak. Proses ini mungkin bermanfaat dalam beberapa penyakit tertentu tetapi di sisi lain dapat bertindak mempercepat penyakit.(8)

Konsekuensi utama dari kematian neuron dopaminergik di substantia nigra pars compacta dan penurunan kadar dopamin adalah gangguan persinyalan dopaminergik dari ganglia basal ke seluruh otak. Pensinyalan eksitasi (merangsang potensial aksi downstream) dan inhibisi dopaminergik terganggu pada otak pasien PD, yang mana memiliki konsekuensi penting bagi upaya terapi yang menargetkan jaringan ini. Persinyalan neuron dopaminergik dari otak tengah memainkan peranan dalam inhibisi aktivitas neuron eksitatorik dari substantia nigra. Proyeksi aksonal dari substantia nigra meluas ke putamen, tempat serangkaian koneksi melalui globus pallidus dan nukleus subthalamik menghasilkan aktivasi sinyal neuron dari thalamus dan kemudian ke korteks motorik, dan menghubungkan ke luar sistem saraf pusat dan untuk memulai aksi dan mengendalikan gerakan. Hilangnya keduanya rangsang dan sinyal penghambat yang berasal dari substantia nigra pars compacta akhirnya akan mengurangi sinyal keluar dari sistem saraf pusat dan berdampak pada kontrol gerakan.(8) 


\section{B.3. Mutasi LRRK2 merupakan monogenetik penyebab PD}

Pada tahun 2004, mutasi pada leusin-rich repeat kinase 2 (LRRK2), sebuah kinase multidomain besar, pertama kali diidentifikasi pada sebuah keluarga dengan PD.(8) Sekarang diketahui bahwa mutasi LRRK2 merupakan salah satu penyebab genetik paling umum dari PD, dengan tingkat yang sangat tinggi di beberapa populasi, sebagian besar terutama pada individu turunan Berber Afrika Utara atau Yahudi Ashkenazi. $(8,10)$

Fenotip klinis dari PD terkait LRRK2 hampir tidak bisa dibedakan dari penyakit idiopatik. Terdapat variasi dalam neuropatologi yang diamati dalam kasus terkait LRRK2. Mayoritas pasien dengan mutasi LRRK2 yang diperiksa post mortem menunjukkan patologi Lewy body. Proporsi yang signifikan tidak memiliki Lewy body tetapi ditemukan neurofibrillary tangles mirip dengan yang terlihat pada kelumpuhan supranuklear progresif, atau dengan deposisi TDP-43 mirip dengan yang diamati pada demensia frontotemporal atau amyotrophic lateral sclerosis.(8)

Pada tingkat molekuler, LRRK2 berfungsi untuk mengatur transportasi endosomal protein dalam sel sehingga berperan dalam fungsi lisosom dan fungsi jalur makroautofagi.(11) Keduanya penting untuk proteostasis seluler. Makroautofagi mengumpulkan protein yang salah lipat untuk didegradasi dan lisosom melakukan proses pembuangan dan daur ulang protein. Dengan demikian gangguan fungsi lisosom dan makroautofagi yang disebabkan mutasi pada LRRK2 dapat mengganggu upaya sel untuk membuang agregat protein.(8)

\section{Gangguan kognitif pada PD}

Gangguan kognitif pada PD bervariasi dalam tingkat perkembangan keparahannya, dan domain kognitif yang terkena. Gangguan kognitif bervariasi dari perubahan atau defisit kognitif yang halus, Mild cognitive impairment (MCI) yang ditandai dengan terjadinya defisit kognitif tetapi tidak signifikan mengganggu kehidupan sehari-hari, hingga demensia (PDD) dengan derajat yang lebih besar dan berbagai defisit kognitif yang secara substansial mempengaruhi aktivitas sehari-hari. MCI di PD berisiko berkembang menjadi demensia. Namun, bukti tambahan menunjukkan bahwa PD-MCI mungkin tidak selalu berkembang menjadi demensia. Pada penilaian longitudinal, beberapa tetap stabil pada tingkat MCI dan pada kasus lainnya fungsi kognitif kembali normal. Dengan demikian, perkembangan menjadi demensia bukan tidak terhindarkan, tetapi berkembang pada sekitar 80\% pasien, terutama dengan durasi PD lebih dari 20 tahun.(4)

Faktor risiko untuk PDD termasuk usia lanjut, onset penyakit, keterbatasan fungsi kognitif, halusinasi, dan lebih dominan pada gangguan gait. Defisit kognitif pada PD biasanya memengaruhi fungsi eksekutif, perhatian, fungsi visuospasial, dan kecepatan pemrosesan. Pola penurunan kognitif bervariasi, tidak hanya pada tingkat di mana domain kognitif yang berbeda terpengaruh tetapi juga domain mana yang terpengaruh terlebih dahulu. Beberapa orang dengan gangguan kognitif PD mungkin memiliki defisit memori yang lebih besar daripada disfungsi non-amnestik.(4) 
Prevalensi demensia pada PD meningkat dengan bertambahnya usia, durasi penyakit, keparahan motorik, fenotip gangguan instabilitas/ketidakstabilan postur tubuh, gangguan kognitif dasar, dan gangguan nonmotor lainnya serta masalah neuropsikiatri. RBD terkait erat dengan gangguan kognitif PD. Isolasi sosial, depresi, dan penyakit medis dapat memperburuk kognisi secara umum dan PD.(4)

Heterogenitas dalam presentasi dan evolusi penurunan kognitif PD tidak sepenuhnya dipahami tetapi mungkin mencerminkan sebagian pengaruh patologi komorbiditas seperti penyakit Alzheimer (AD) atau penyakit serebrovaskular serta faktor genetika, dan lingkungan. Studi CamPaIGN menunjukkan heterogenitas subtipe penurunan kognitif PD dan tingkat perkembangan yang berbeda. Terdapat dua subtipe kognitif yang berbeda dalam penelitian longitudinal ini yaitu:

(1) Profil fungsi frontostriatal / eksekutif yang terkait dengan penipisan dopamin berinteraksi dengan genotipe catechol-O-methyltransferase (COMT) dan tidak selalu berkembang menjadi demensia.(4) COMT merupakan gen pengkode enzim pendegradasi katekolamin. Mutasi pada COMT menyebabkan peningkatan degradasi dopamin di korteks area prefrontal. $(12,13)$

(2) Profil fungsi kortikal posterior dengan defisit pada gangguan bahasa/semantik, kelancaran dan orientasi visuospasial/penyalinan pentagon, terkait dengan patologi $\mathrm{AD}$, transmiter non-dopaminergik, dan genotipe apolipoprotein epsilon 4 (ApoE4). (4)

PD-MCI cenderung heterogen, dapat dikelompokan menjadi subtipe domain tunggal dan multiple domain; masing-masing dapat menunjukkan kerusakan pada domain amnestik atau non-amnestik (misalkan disfungsi eksekutif atau visuospatial). Meskipun pasien dengan PD-MCI sering menderita gangguan dalam berbagai domain kognitif, seperti disfungsi eksekutif, perhatian, kecepatan pemrosesan, kemampuan visuospatial, pembelajaran dan memori, sebagian besar pasien menunjukkan subtipe non-amnestik dibandingkan dengan dominasi gangguan memori pada MCI karena penyakit Alzheimer. Defisit kognitif yang terkait dengan PD-MCI cenderung bersifat non-amnestik dan mungkin melibatkan disfungsi berbasis frontal yang lebih besar, termasuk fungsi eksekutif dan perhatian/defisit working memory. Namun, temuan yang bertentangan juga ada. Sebagai contoh, kerusakan memori ditemukan sebagai domain paling umum yang terkena dampak PD-MCI dalam beberapa penelitian. (14)

Meskipun pasien dengan PD-MCI tidak selalu berubah menjadi demensia, beberapa penelitian menunjukkan bahwa pada umumnya, pasien dengan PD-MCI menunjukkan resiko yang lebih besar terkena demensia, dibandingkan dengan pasien PD yang tidak mengalami penurunan fungsi kognitif. Masih belum jelas subtipe mana yang lebih mungkin menyebabkan demensia. Ada kemungkinan bahwa fungsi kognitif posterior terkait dengan perkembangan yang lebih cepat menjadi demensia, sementara disfungsi eksekutif frontal terkait dengan perkembangan yang lebih lambat dan dengan prognosis yang lebih baik. Penelitian lain menunjukkan bahwa kinerja frontal/eksekutif yang buruk dapat memprediksi perkembangan terjadinya demensia. Disfungsi eksekutif maupun defisit memori dapat memprediksi terjadinya demensia pada PD. Dalam studi lain diketahui bahwa fungsi kognitif posterior (misal memori dan kemampuan visuospasial) terkait dengan perkembangan demensia. (14) 


\section{Gambaran umum patologi penurunan kognitif PD}

PD-MCI ditandai oleh atrofi kortikal, terutama yang melibatkan lobus temporal anterior kanan, prefrontal kiri dan insular, dan daerah parietal dan oksipital kanan. Atropi yang berlanjut ke area subkortikal juga merupakan perjalanan patologi. Teknik pencitraan diffusion tensor imaging (DTI) dan diffusion-weighted imaging magnetic resonance imaging (MRI) digunakan untuk menyelidiki daerah otak tersebut. Sebuah studi yang bertujuan mengidentifikasi perubahan neuroanatomi spesifik pada pasien drug-naive PD-MCI dengan menggunakan voxel-based morphometry (VBM) menunjukkan bahwa pasien mengalami atrofi di korteks entorhinal kanan dibandingkan dengan pasien PD dengan fungsi kognitif normal. (15)

Sebuah studi dengan functional MRI mendokumentasikan hiperaktivitas (yang mencerminkan mekanisme kompensasi) di bagian opercular gyrus frontal kanan inferior dan hipoaktivitas (yang terkait dengan penurunan kognitif) di daerah oksipital penderita PD pada awal terjadinya MCI. Studi yang dilakukan dengan positron emission tomography with f18-fluorodeoxyglucose (FDG-PET) menunjukkan penurunan metabolisme daerah kortikal otak posterior pasien PD-MCI. Pencitraan dengan single-photon emission computed tomography imaging of dopamine transporters (DAT-SPECT) menunjukkan terjadinya penurunan uptake dopamin pada nukleus kaudatus dapat memprediksi terjadinya penurunan kognitif pada PD. (15)

Studi neuropatologis dari pasien yang meninggal dengan PDD menunjukkan keterlibatan neurodegenerasi daerah kortikal dan limbik yang luas, kehilangan neuron, dan deposisi Lewy body dan Lewy neurites. Patologi ganglia basal, terutama pada daerah asosiatifnya (kognitif), juga dapat berkontribusi terhadap defisit kognitif. (4) Studi terbaru menunjukkan bahwa kelainan white matter, seperti yang ditunjukkan oleh DTI, mendahului atrofi gay matter pada demensia PD, meskipun peran degenerasi white matter dalam penurunan kognitif pada PD masih diperdebatkan. (15)

PD merupakan penyakit yang dimediasi $\alpha$-synuclein. Studi otopsi dan biomarker cairan serebrospinal menunjukkan bahwa patologi amiloid berkontribusi terhadap penurunan kognitif pada PD di beberapa kasus. Sinuklein dan amiloid mungkin berperan secara sinergis. Penyakit serebrovaskular berkontribusi untuk beberapa kasus gangguan kognitif PD, yang dibuktikan dengan iskemia mikrovaskular pada patologi hiperintensitas subtansia alba dengan neuroimaging. Gangguan kognitif PD juga mencerminkan defisiensi neurotransmitter dopaminergik, kolinergik, serotonergik, dan noradrenergik. Functional neuroimaging dan studi neuropatologis menunjukkan keterlibatan defisit neurotransmitter dopaminergik dan kolinergik pada gangguan kognitif PD.(4)

Neuroinflamasi memainkan peran penting dalam beberapa penyakit neurodegeneratif, termasuk PD. Pada PD, hilangnya neuron dopaminergik disertai dengan perubahan inflamasi pada mikroglia, astrosit, sel imun innate, serta infiltrasi sel imun perifer. Neuroinflamasi mungkin merupakan respons imun mendasar untuk melindungi neuron dari kerusakan dan mengkompensasi kerusakan neuron, tetapi pada saat yang sama, efek neurotoksiknya memperburuk kerusakan neuron. Dalam kondisi neuropatologis, mikroglia diaktifkan oleh kerusakan otak dan meningkatkan respons inflamasi dengan mengeluarkan sitokin dan kemokin proinflamasi. Mikrogliosis pertama kali terjadi pada otak tengah, dan juga teramati pada putamen, hipokampus, dan korteks pasien PD. (16) 
Terdapat hubungan antara SVD dengan gejala motorik dan kognitif pada PD.(15) SVD dianggap merusak kognisi dengan mengganggu efisiensi jalur white matter yang menghubungkan jaringan yang mendasari proses kognitif.(17) SVD meliputi hiperintensitas white matter (seiring bertambahnya usia otak mulai menghasilkan microbleeds dan lesi dalam materi putih yang dapat dideteksi sebagai WMH), lakuna, ruang perivaskular, dan microbleeds, memiliki keterkaitan dengan penurunan fungsional dan kognitif pada pasien PD. Namun, kurangnya kriteria yang seragam dan teknik pencitraan standar saat ini menghambat kemajuan penelitian dalam mengeksplorasi hubungan antara penyakit serebrovaskular dan PD. (15,18)

Beberapa penyebab atau faktor risiko genetik untuk PD (misal LRRK2) umumnya tidak terkait dengan disfungsi kognitif yang menonjol, sedangkan duplikasi $\alpha$-synuclein, mutasi glucocerebrosidase beta (GBA, gen pengkode enzim yang terdapat di lisosom) dan mutasi microtubule associated protein tau (MAPT) telah dikaitkan dengan defisit kognitif dan demensia.(19,20). Alel ApoE4 berkaitan dengan memori dan kelancaran semantik pada PD dan mungkin meningkatkan risiko PDD. Studi lain menunjukkan peran polimorfisme dalam gen BDNF dan COMT pada gangguan kognitif PD.(4)

Pada populasi non-PD, komorbiditas seperti obesitas, diabetes, dan hipertensi dapat dikaitkan dengan penurunan kognitif. Hal ini juga berlaku untuk diet tinggi lemak jenuh, trans-lemak, dan karbohidrat, atau kurangnya konsumsi beri, sayuran berdaun hijau, kacang-kacangan, vitamin B12, dan folat. Saat ini, data mengenai peran komorbiditas dan diet dalam penurunan kognitif PD masih terbatas.(4)

\section{KESIMPULAN}

Penyakit Parkinson adalah penyakit neurodegeneratif yang dicirikan dengan gangguan motorik (bradikinesia, tremor istirahat, kekakuan, dan instabilitas postural), onset gejala asimetris, dan respon yang baik untuk levodopa. Neuropatologis utama PD adalah keberadaan Lewy bodies yang mengandung $\alpha$-synuclein dan hilangnya neuron dopaminergik di substantia nigra, yang bermanifestasi penurunan fasilitasi gerakan sadar. Dengan perkembangan PD, patologi Lewy bodies menyebar ke daerah neokortikal dan kortikal. Penurunan kognitif, dalam bentuk penurunan eksekutif, penurunan visuospatial dan memori, serta demensia, merupakan aspek non-motorik dari penyakit parkinson. Neurodegenerasi daerah kortikal dan limbik yang luas, deposisi Lewy bodies, neuroinflamasi, SVD, dan faktor genetik terlibat dalam penurunan fungsi kognitif pada PD. 


\section{DAFTAR PUSTAKA}

1. Tysnes OB \& Storstein A. Epidemiology of Parkinson's disease. J Neural Transm. 2017;124(8):901-5. doi: 10.1007/s00702-017-1686-y

2. Kouli A, Torsney KM, Kuan W. Parkinson's disease: Etiology, neuropathology, and pathogenesis. Parkinson's Disease: Pathogenesis and Clinical Aspects. Stoker TB, Greenland JC (Editors). Brisbane: Codon Publications; 2018. Doi: http://dx.doi. org/10.15586/codonpublications.parkinsonsdisease.2018. chl

3. Weil RS, Costantini AA, Schrag AE. Mild cognitive impairment in Parkinson's disease — What Is It ?. Curr Neurol Neurosci Rep (2018) 18:17. doi:10.1007/s11910-018-0823-9

4. Goldman JG, Vernaleo BA, Camicioli R, Dahodwala N, Dobkin RD, Ellis T, et al. Cognitive impairment in Parkinson's disease: a report from a multidisciplinary symposium on unmet needs and future directions to maintain cognitive health. npjParkinson's Disease (2018) 4:19; doi:10.1038/s41531-018-0055-3

5. Balestrino R \&Schapira AHV. Parkinson disease. European Journal of Neurology 2020;27: $27-4$. doi:10.1111/ene. 14108

6. Muangpaisan W, Hori2 H \& Brayne C. Systematic review of the prevalence and incidence of parkinson's disease in Asia. Epidemiol 2009;19(6):281-293. doi:10.2188/jea.JE20081034

7. Kaiyrzhanov R, Rizig M, Aitkulova A, Zharkinbekova N, Shashkin C, Kaishibayeva G, Karimova A, et al. Parkinson's disease in Central asian and Transcaucasian countries: A review of epidemiology, genetics, clinical characteristics, and access to care. Hindawi Parkinson's Disease Volume 2019, doi: https://doi.org/10.1155/2019/2905739

8. Lewis, PA, \& Spillane JE. Neurodegenerative disease 1st edition. Cambridge: Academic Press; 2018. p. 83-121.

9. Kehagia AA, Barker RA, Robbins TW. Neuropsychological and clinical heterogeneity of cognitive impairment and dementia in patients with Parkinson's disease. Lancet Neurol. 2010;9(12):1200-13. doi:10.1016/S1474-4422(10)70212-X

10. Paisán-Ruiz C, Lewis PA, Singleton AB. LRRK2: Cause, risk, and mechanism. J Parkinsons Dis. 2013;3(2):85-103. doi:10.3233/JPD-130192

11. Roosen DA, Cookson MR. LRRK2 at the interface of autophagosomes, endosomes and lysosomes. Mol Neurodegener. 2016;11(1):1-10. doi:10.1186/s13024-016-0140-1

12. Brotchie J, Bezard E, Jenner P. Pathophysiology, pharmacology and biochemistry of dyskinesia. International Review of Neurobiology. Cambridge: Academic Press; 2011. 98(1). p.664. 
13. Jin J, Liu L, Gao Q, Chan RCK, Li H, Chen Y, et al. The divergent impact of COMT Val158Met on executive function in children with and without attention-deficit/hyperactivity disorder. Genes, Brain and Behavior (2016) 15: 271-279. doi: 10.1111/gbb.12270

14. Wen MC, Chan LL, Tan LCS \& Tan EK. Mild cognitive impairment in Parkinson's disease: a distinct clinical entity?. Translational Neurodegeneration (2017) 6:24. doi: 10.1186/s40035-017-0094-4

15. Cammisuli DM, Cammisuli SM, Fusi J, Franzoni F \& Pruneti C. Parkinson's disease-mild cognitive impairment (PD-MCI): A useful summary of update knowledge. Front. Aging Neurosci. 11:303. doi: 10.3389/fnagi.2019.00303

16. Lee Y, Lee S, Chang SC, Lee J. Significant roles of neuroinflammation in Parkinson's disease: therapeutic targets for PD prevention. Arch. Pharm. Res. 2019. https://doi.org/10.1007/s12272-019-01133-0

17. Benjamin P, Lawrence AJ,Lambert C, Patel B,Chung AW, MacKinnon AD, et al. Strategic lacunes and their relationship to cognitive impairment in cerebral small vessel disease. Neuroimage Clin. 2014; 4: 828-837. doi: 10.1016/j.nicl.2014.05.009

18. D'Arbeloff T, Elliott ML, Knodt AR, Melzer TR, Keenan R, Ireland D, et al. White matter hyperintensities are common in midlife and already associated with cognitive decline, Brain Communications, Vol 1, Issue 1, 2019, fcz041, https://doi.org/10.1093/braincomms/fcz041

19. Barbier P, Zejneli O, Martinho M, Lasorsa A, Belle V, Smet-Nocca C. Role of tau as a- microtubule associated protein: structural and functional aspects. Front. Aging Neurosci. 2019.8(7) doi: 10.3389/ fnagi.2019.00204.

20. Do J, McKinney C, Sharma P, Sidransky E. Glucocerebrosidase and its relevance to Parkinson disease. Mol Neurodegener. 2019;14(1):1-16. doi:10.1186/s13024-019-0336-2 